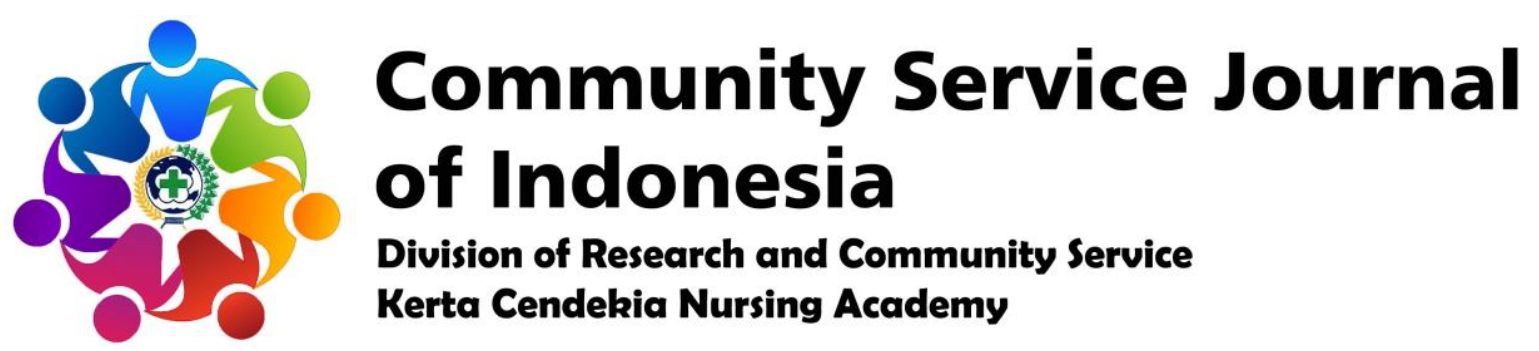

https://ejournal-kertacendekia.id/index.php/csji/index

Community Service Journal of Indonesia 1 (2) (2019): 28-30

Doi: https://doi.org/10.36720/csji.v1i2.135

\title{
IMPROVED KNOWLEDGE OF FIRST AID IN CHOKE
}

\author{
Riesmiyatiningdyah Riesmiyatiningdyah ${ }^{1}$, Nurinah Nurinah ${ }^{2}$, Nadia Dhita Bela Santika \\ $\mathrm{RM}^{2}$, Eka Wahyuni Alviana $\mathrm{S}^{2}$, Agustina Mei Lerebulan ${ }^{2}$, Winda Puspa Sari ${ }^{2}$ \\ ${ }^{1}$ Lecturer of Kerta Cendekia Nursing Academy, Sidoarjo \\ ${ }^{2}$ Student of Kerta Cendekia Nursing Academy, Sidoarjo
}

\begin{abstract}
Health promotion activities about the first handling of choking in the Rangkah Kidul Elementary School, Sidoarjo is one form of community service in the form of counseling aimed at increasing children's knowledge about how to handle choking events which are events that often occur to cause death. The implementation of these activities on November 13, 2019 took place at the Rangkah Kidul Elementary School, Sidoarjo. The target is elementary students in Rangkah Kidul, Sidoarjo. Before the activity is carried out, there is a process of compiling the activity for approximately 3 weeks before the activity is carried out, starting from determining the theme of counseling to submitting permits to the parties concerned. As a form of evaluation, the activity was attended by 33 students and 1 teacher, participants participated in the activity happily and looked very enthusiastic, health promotion activities could run on time and smoothly.
\end{abstract}

Keywords: Choke, first aid, health promotion.

\section{INTRODUCTION}

Choking is a respiratory condition that is still often underestimated by the public. According to the data, the death rate caused by airway obstruction especially choking is still high among infants (Dwiadhi, 2013 in Utami, 2014). Choking cases also afflict many school children, especially elementary school children with various causes, for example children eating food while talking. Choking events must be dealt with immediately to avoid victims of lack of oxygen, difficulty breathing, even death.

\section{OBJECTIVES}

General Purpose

After the health promotion carried out by the health promotion implementers for 40 minutes, it is hoped that the $6^{\text {th }}$ grade students of Rangkah Kidul Elementary School, Sidoarjo can understand how to handle choking in children. 
Special Purpose

After 40 minutes of health education carried out by students, it is hoped that students in the $6^{\text {th }}$ grade students of Rangkah Kidul Elementary School, Sidoarjo can be:

1. Able to know the definition of choking.

2. Able to know the signs of choking.

3. Able to find out how to first aid in a choking situation.

4. Able to know how to prevent choking.

\section{PLAN OF ACTION}

\section{Strategy Plan}

The strategy plan implemented, including:

1. Coordinate with the principal of Rangkah Kidul Elementary School, Sidoarjo to request permission to carry out health education as a nursing program and to help provide useful knowledge for students in Rangkah Kidul Elementary School, Sidoarjo.

2. Establish time contracts with students at Rangkah Kidul Elementary School, Sidoarjo.

3. Provide health education about first aid on choking.

\section{Implementation}

Actions taken in the implementation of these activities, including:

1. Contacted the principal of Rangkah Kidul Elementary School, Sidoarjo to request permission to carry out these activities and gathered students from Rangkah Kidul Elementary School, Sidoarjo.

2. Prepare a place and counseling media.

3. Submission of health promotion materials about first aid in choking to students at Rangkah Kidul Elementary School, Sidoarjo.
Setting

This activity was carried out at Rangkah Kidul Elementary School, Sidoarjo.

Target

Target in this activity is all of the $6^{\text {th }}$ grade students of Rangkah Kidul Elementary School, Sidoarjo.

\section{RESULTS AND DISCUSSION}

The health promotion activity was carried out on Wednesday, November 13, 2019 at 10:00 WIB in the 6th grade of Rangkah Kidul Elementary School, Sidoarjo. The schedule is in accordance with the planned schedule.

The counseling participants were 33 students from the 6th grade of Rangkah Kidul Elementary School, Sidoarjo. Participants who attended seemed enthusiastic and no one left the room before the event was over. Rangkah Kidul Elementary School teacher, Sidoarjo wants to work together in carrying out this health promotion activity. Equipment used during the counseling process are laptops, PowerPoints, videos, leaflets, LCDs, posters. Using simple language and sentences, students at Rangkah Kidul Elementary School responded with enthusiasm. Questions asked by participants can be answered by all team members.

Based on the results of the final evaluation conducted by the health promotion team, $90 \%$ of participants were able to mention the meaning of choking, $90 \%$ of participants could mention signs of choking, $70 \%$ of participants could redemonstrate the handling of choking, and 95\% of participants could understand ways to prevent choking. 


\section{CONCLUSION}

Improved knowledge of first aid in choke through health promotion was considered quite successful because $90 \%$ of participants were able to mention the meaning of choking, $90 \%$ of participants could mention signs of choking, $70 \%$ of participants could re-demonstrate the handling of choking, and $95 \%$ of participants could understand ways to prevent choking.

\section{REFERENCES}

Bagian Diklat RSCM. (2015). Tersedak: Pelatihan Internal RSCM Bantuan Hidup Dasar 2015. Jakarta: Bagian Diklat RSCM.

Pusponegoro, A.D., et al. (2012). Basic Trauma Life Support \& Basic Cardiac Life Support. Edisi kelima. Jakarta: Yayasan Ambulans Gawat Darurat 118.

Sumarningsih, D. (2015). Pengaruh Edukasi Keluarga Tentang Pencegahan Dan Penanganan Tersedak Pada Anak Terhadap Pengetahuan tersedak. Retrieved from http://opac.say.ac.id/201/1/NASKAH \%20PUBLIKASI.pdf on October 9, 2019.

Tim Bantuan Medis BEM IKM FKUI. (2015). Modul bantuan hidup dasar dan penanganan tersedak. Jakarta: Universitas Indonesia.

Utami, D. S. (2014). Teknik Mencegah Bayi Tersedak Pada Ibu Menyusui Di Puskesmas Pembantu Desa Demung Besuki Situbondo. KTI D3 Kebidanan. 